\title{
Study the Efficacy of Chemicals on the Quality Parameters of Guava (Psidium guajava L) cv. Lucknow - 49
}

\author{
Divyashree Saikia $^{1 *}$ and Utpal Kotoky ${ }^{2}$
}

Department of Horticulture, Assam Agricultural University, Jorhat- 785013 (Assam), India

*Corresponding author

\section{Keywords}

Plant growth hormones, Guava, NAA, NAD, Urea, Chemical parameters

Article Info

Accepted:

12 December 2018

Available Online:

10 January 2019

\section{A B S T R A C T}

Plant growth hormones are the chemicals, which in small amount promote growth, development and differentiation of cells and tissues. It plays a vital role in guava production and helps in the induction of flowering, fruiting buds development, fruit set, fruit thinning, fruit elongation, premature fruit drop prevention, and inhibiting ripening process. An investigation was conducted to study the efficacy of chemicals on the quality parameters of guava in the Experimental Farm and Laboratory, Department of Horticulture, College of Agriculture, Assam Agricultural University, Jorhat during 20162018. A total of 6 (six) treatments with four replications and two seasons (rainy and winter) were laid out in a Randomized Block Design. The treatments comprised of $\mathrm{T}_{1}-$ Naphthalene acetic acid (NAA at $100 \mathrm{ppm}$ ), $\mathrm{T}_{2}-$ Naphthalene acetamide (NAD at 40 $\mathrm{ppm}), \mathrm{T}_{3}-$ Naphthalene acetamide (NAD at $60 \mathrm{ppm}$ ), $\mathrm{T}_{4}$ - Urea (2\%), $\mathrm{T}_{5}$ - Urea (5\%) and $\mathrm{T}_{6}$ - Urea (10\%) which were applied during the flowering in the month of April, 2017. It helped in deblossoming of flowers, increase the yield $(20.73 \mathrm{~kg} / \mathrm{plant})$, juice content $(48.45 \%)$, TSS $\left(10.73^{\circ} \mathrm{Brix}\right)$, reducing sugar $(3.74 \%)$, non-reducing sugar $(3.10 \%)$, total sugar $(6.82 \%)$, sugar acid ratio (45.46), pectin content (3.42\%), ascorbic acid (264.18 $\mathrm{mg} / 100 \mathrm{~g})$ and also decrease the titrable acidity $(0.15 \%)$. NAD @ 60ppm was recorded to be the best treatment to fulfill the quality parameters of guava in the winter season.

\section{Introduction}

Guava, the 'apple of tropics' is the most important commercial fruit crop grown in subtropical region of the Indian subcontinent. It gives an assured crop with low cost of production as compared to most of other commercial fruit crops. It has gained considerable prominence on account of its high nutritive value, cheap and easily availability at moderate prices. India is the leading producer of guava in the world and the fruit occupies a place of considerable importance in the fruit economy of the country. In the north-eastern region of India, Assam claims to be in the $11^{\text {th }}$ position in growing Guava (Anon, 2015) but its productivity is far below the national average due to poor fruit set and high fruit drop (Ojah, 2013).

In Assam, Guava bears two seasons only i.e. Rainy and winter season. The rainy season fruits are insipid, rough (Ojah, 2013) and are 
affected by many biotic and abiotic stresses. The quality of the fruits is inferior, less nutritive due to high temperature and humidity and are also affected by many pest and diseases and infected by fruit flies (Sharma et al., 2016). It has maximum yield but low demand in the market. The winter season fruits are more demanded for more nutritive, superior quality, high sugar content with a good aroma, free from pest and diseases but the yield is low. Thus, the winter season fruits should be preferred more and are advisable to take one crop in a year. Keeping these facts in view, a systematic study by using plant growth hormones was undertaken to study the efficacy of chemicals on the quality parameters of guava (Psidium guajava L) cv. Lucknow - 49 for improving the chemical parameters of the fruit in the winter season during 2016-2018.

\section{Materials and Methods}

The research work entitled "Study the efficacy of chemicals on the quality parameters of guava (Psidium guajava L) cv. Lucknow -
49" was conducted in the Experimental Farm, Department of Horticulture, College of Agriculture, Assam Agricultural University, Jorhat during 2016-2018. The experimental site was situated at $26^{\circ} 47^{\prime} \mathrm{N}$ latitude and $94^{\circ} 12^{\prime} \mathrm{E}$ longitude having an elevation of $86.8 \mathrm{~m}$ above mean sea level. The guava orchard with an area of $1728 \mathrm{~m}^{2}$ was well maintained with a spacing of $6 \mathrm{~m} \times 6 \mathrm{~m}$ apart from each plant. A total of six treatments with four replications, two plants in each treatment were laid out in the randomized block design. The treatments with different concentrations of NAA (100 ppm), NAD (40 ppm and 60 ppm) and Urea (2\%, 5\% and 10\%) were sprayed twice in the month of April, 2017. First spray was in the first week of April at the flowering stage and the second spray was after 10 days of the first spray. The changes in the chemical parameters of the fruit in the winter season than the rainy season were determined by different formulas -To find the TSS of the fruit, the fresh fruit was cut into pieces and squeeze out. The juice obtained was determined by Zeiss Hand Refractometer and expressed in percentage.

Titrable Acidity $=\frac{\text { Titre value } \times \text { Normality } \quad \text { of alkali } \times \text { Volume } \quad \text { made up } \times \text { Equivalent } \text { weight of citric acid }}{\text { Wt of sample } \times \text { Aliquot } \times 10}$

Reducing sugars $(\%)=\left[\frac{\mathrm{mg} \text { of invert } \text { sugar } \times \text { Dilution } \times 100}{\text { Titre } \times \mathrm{Wt} \text { of sample } \times 1000}\right]$

Non-reducing sugars $(\%)=$ Total sugar $(\%)-$ Reducing sugar $(\%)$

Total sugar $=\%$ sucrose $+\%$ reducing sugar

The ratio of sugar to acid was determined by dividing the percent of total sugar with the percent total acidity. Pectin content is expressed as a percentage of calcium pectate.
To find out the fruit juice, the fruit was cut into pieces at over ripe stage and squeezed and juice was expressed in percent.

Ascorbic acid $(\mathrm{mg} / 100 \mathrm{gm})=\frac{\text { Titre value } \times \text { Dye factor } \times \text { Volume made up }}{\text { Aliquot of extract ta ken for estimation } \times \text { Weight/Vo lume of sample taken for estimation }} \times 100$ 


\section{Statistical analysis}

Significance and non-significance of variance due to the different concentrations of NAA, NAD and Urea were determined by calculating the respective ' $F$ ' values (Panse and Sukhatma, 1985). Critical difference (CD) at $5 \%$ probability level were calculated only when ' $F$ ' value was significant.

\section{Results and Discussion}

\section{Titrable acidity}

Table 1 shows a significant difference in titrable acidity due to various treatments. $\mathrm{T}_{4}$ (2\% Urea) recorded the highest titrable acidity of $0.36 \%$ and $0.25 \%$ followed by $0.33 \%$ and $0.24 \%$ under $\mathrm{T}_{6}(10 \%$ Urea) during both the rainy and the winter seasons. Similarly, the lowest titrable acidity of $0.26 \%$ and $0.15 \%$ was recorded under treatment $T_{3}(60 \mathrm{ppm}$ NAD) during both the rainy and the winter season respectively. The interaction effect of seasons and treatments were found to be nonsignificant.

The reason for reduction in acidity with the application of NAD @60ppm might be due to the rapid utilization of organic acid as the respiratory substrate in respiration process at maturity. It might also be due to the early ripening of fruits where acid might have been used during respiration or firstly converted into sugars. Similar results were obtained by Rajput et al., (1977), Singh et al., (1992) and Dubey et al., (2002).

\section{Total Soluble Solid (TSS)}

$\mathrm{T}_{3}$ (60 ppm NAD) recorded the highest TSS of $9.13^{\circ}$ Brix during the rainy season followed by $8.30^{\circ}$ Brix in $\mathrm{T}_{2}$ (40 ppm NAD) whereas in the winter, the highest $\operatorname{TSS}\left(10.73^{\circ} \mathrm{Brix}\right)$ was recorded under $\mathrm{T}_{3}$ (60 ppm NAD) followed by $10.46^{\circ} \mathrm{Brix}$ in $\mathrm{T}_{1}$ (100 ppm NAA). The interaction effect of seasons and treatments were found to be significant. The highest TSS of $9.93^{\circ} \mathrm{Brix}$ was recorded in $\mathrm{T}_{3}(60 \mathrm{ppm}$ NAD) followed by $9.14^{\circ}$ Brix under $T_{2}$ (40 ppm NAD). However, the treatments $T_{2}$ (40 ppm NAD) and $\mathrm{T}_{5}(5 \%$ Urea) were statistically at par (Table 2).

According to Boora et al., (2016), total soluble solids are the index of sweetness of fruit. The appreciable improvement in total soluble solids (TSS), due to the application of growth substances might be due to the quick metabolic transformation of starch into sugars and rapid mobilization of photosynthetic metabolites and minerals from other parts of the plant to the developing fruits (Maji et al., 2015).

\section{Reducing sugar and non- reducing sugar}

The data presented in Table 3 revealed that in both the rainy and the winter season the highest reducing sugar content of $2.94 \%$ and $3.74 \%$ was recorded in $\mathrm{T}_{3}$ (60 ppm NAD) followed by $2.92 \%$ and $3.68 \%$ in $\mathrm{T}_{1}(100 \mathrm{ppm}$ NAA).

The interaction effect of treatments and the seasons were found to be significant. The highest reducing sugar content was recorded in $\mathrm{T}_{3}$ (60 ppm NAD) as 3.33\% followed by $3.30 \%$ in $\mathrm{T}_{1}$ (100 ppm NAA). However, the three treatments $\mathrm{T}_{1}$ (100 ppm NAA), $\mathrm{T}_{2}$ (40 ppm NAD), and $T_{3}(60 \mathrm{ppm}$ NAD) were found to be non-significant.

Non-reducing sugar content of fruit was significantly influenced by various treatments which were shown in Table 4. The highest non-reducing sugar content of $2.48 \%$ and $3.10 \%$ was recorded in $\mathrm{T}_{3}$ (60 ppm NAD) followed by $2.24 \%$ and $3.08 \%$ in $\mathrm{T}_{1}(100 \mathrm{ppm}$ $\mathrm{NAA}$ ) and $2.24 \%$ in $\mathrm{T}_{5}(5 \%$ Urea).

The interaction effect of treatments and seasons were found to be significant. The highest non-reducing sugar content was 
recorded in $\mathrm{T}_{3}$ (60 ppm NAD) as $2.79 \%$ followed by $2.66 \%$ in $\mathrm{T}_{1}$ (100 ppm NAA). However, the treatments $\mathrm{T}_{1}$ (100 ppm NAA) and $\mathrm{T}_{5}(5 \%$ Urea) was statistically at par with $\mathrm{T}_{2}$ (40 ppm NAD). The reason for increase in the content of reducing sugar and nonreducing sugar in winter might be due to delay in ripening of fruits, hence provided a long period of fruits to be remained on tree during which they accumulated more carbohydrates within them (Singh, 1986). Similar results were obtained by Kumar and Hoda (1977) and Mitra et al., (1982) when they treated the guava plant with the treatment NAD at 50 ppm or $30 \mathrm{ppm}$.

\section{Total sugar}

The data presented in Table 5 revealed that in both the rainy and the winter season the highest total sugar content of $5.42 \%$ and $6.82 \%$ was recorded in $\mathrm{T}_{3}$ (60 ppm NAD) followed by $5.16 \%$ and $6.78 \%$ in $\mathrm{T}_{1}(100 \mathrm{ppm}$ NAA) and the lowest of $4.62 \%$ and $6.03 \%$ was in $\mathrm{T}_{4}(2 \%$ Urea).

The interaction effect of treatments and the seasons were found to be significant. The highest total sugar content of $6.12 \%$ was recorded in $\mathrm{T}_{3}$ (60 ppm NAD) followed by $5.98 \%$ in $\mathrm{T}_{1}$ (100 ppm NAA). However, the non-significant differences was observed in the treatments $\mathrm{T}_{1}$ (100 ppm NAA), $\mathrm{T}_{2}$ (40 ppm NAD) and $\mathrm{T}_{5}(5 \%$ Urea) respectively.

The rainy season guava fruits were not so sweet to taste as compared to the winter fruit as it contain more water and insipid in taste due to greater utilization of sugars (Ojah, 2013). This increase in content of total sugars in winter season fruits was due to the degradation of polysaccharides into simple sugars by metabolic activities, conversion of organic acids into sugars and loss of moisture (Kumar, 2012). The similar finding was observed by Shanker (2003) in guava.

\section{Sugar: acid ratio}

In Table $6, \mathrm{~T}_{3}(60 \mathrm{ppm}$ NAD) recorded the highest sugar acid ratio of 20.84 followed by 18.42 in $\mathrm{T}_{1}$ (100 ppm NAA) during the rainy and the winter season.

The interaction effect of seasons and treatments were found to be significant in Table 6. The highest sugar acid ratio of 33.15 was recorded in $\mathrm{T}_{3}(60 \mathrm{ppm}$ NAD) followed by 30.33 under $\mathrm{T}_{1}$ (100 ppm NAA). The lowest sugar acid ratio of 18.47 was recorded in $\mathrm{T}_{4}(2 \%$ Urea).

The increased in sugar acid ratio with auxins application might be attributed to increase sugar content and reduced level of titrable acidity. The increase in TSS, sugar content and decrease in acidity with the application of bioregulators results the maximum sugar: acid ratio when treated with $60 \mathrm{ppm}$ NAD in guava plant (Maji et al., 2015). The similar improvement in fruit quality in guava through deblossoming with NAD, NAA, Urea had also been reported by Dubey et al., (2002), Sanjay and Kumar (2004), Dutta and Banik (2006), Tiwari and Lal (2007), and Singh (2008).

\section{Pectin content}

In both the rainy and winter seasons $T_{3}(60$ ppm NAD) recorded the highest pectin content of $2.83 \%$ and $3.42 \%$ followed by $2.61 \%$ and $3.36 \%$ in $\mathrm{T}_{1}$ (100 ppm NAA). Similarly, the lowest pectin content of $1.72 \%$ and $3.11 \%$ was recorded under treatment $\mathrm{T}_{4}(2 \%$ Urea).The interaction effect of seasons and treatments were found to be significant in the Table 7 . The highest pectin content of $3.14 \%$ was recorded in $\mathrm{T}_{3}$ (60 ppm NAD) followed by $2.98 \%$ under $\mathrm{T}_{1}$ (100 ppm NAA). The auxin might increase the synthesis of pectic acid or it might lead to enhanced methylation of soluble pectin due to which there might be increase in the highest pectin content in the winter season. 
Table.1 Titrable acidity $(\%)$

\begin{tabular}{|l|c|c|c|}
\hline \multicolumn{1}{|c|}{ Treatment } & Rainy season & Winter season & Pooled \\
\hline $\mathbf{T}_{\mathbf{1}}(\mathbf{1 0 0} \mathbf{~ p p m ~ N A A )}$ & 0.28 & 0.16 & 0.22 \\
\hline $\mathbf{T}_{\mathbf{2}} \mathbf{( 4 0} \mathbf{~ p p m ~ N A D )}$ & 0.29 & 0.17 & 0.23 \\
\hline $\mathbf{T}_{\mathbf{3}}(\mathbf{6 0} \mathbf{~ p p m ~ N A D )}$ & 0.26 & 0.15 & 0.20 \\
\hline $\mathbf{T}_{\mathbf{4}} \mathbf{( 2 \%}$ Urea) & 0.36 & 0.25 & 0.30 \\
\hline $\mathbf{T}_{\mathbf{5}} \mathbf{( 5 \%}$ Urea) & 0.32 & 0.23 & 0.27 \\
\hline $\mathbf{T}_{\mathbf{6}} \mathbf{( 1 0 \%}$ Urea) & 0.33 & 0.24 & 0.28 \\
\hline Mean & 0.31 & 0.20 & 0.25 \\
\hline S.Ed & 0.014 & 0.014 & \\
\hline CD - 5\% & 0.030 & 0.030 & \\
\hline & $\mathbf{S . E d}$ & $\mathbf{C D}-\mathbf{5 \%}$ & \\
\hline Treatment & 0.016 & 0.033 & \\
\hline Season & 0.005 & 0.012 & NS \\
\hline Season $\mathbf{T r e a t m e n t}$ & 0.014 & & \\
\hline
\end{tabular}

Table.2 TSS (o Brix)

\begin{tabular}{|l|c|c|c|}
\hline \multicolumn{1}{|c|}{ Treatment } & Rainy season & Winter season & Pooled \\
\hline $\mathbf{T}_{\mathbf{1}} \mathbf{( 1 0 0} \mathbf{~ p p m ~ N A A )}$ & 6.77 & 10.46 & 8.62 \\
\hline $\mathbf{T}_{\mathbf{2}} \mathbf{( 4 0} \mathbf{~ p p m ~ N A D )}$ & 8.30 & 9.98 & 9.14 \\
\hline $\mathbf{T}_{\mathbf{3}}(\mathbf{6 0} \mathbf{~ p p m ~ N A D )}$ & 9.13 & 10.73 & 9.93 \\
\hline $\mathbf{T}_{\mathbf{4}} \mathbf{( 2 \%}$ Urea) & 7.98 & 8.48 & 8.23 \\
\hline $\mathbf{T}_{\mathbf{5}} \mathbf{( 5 \%}$ Urea) & 7.93 & 9.72 & 8.83 \\
\hline $\mathbf{T}_{\mathbf{6}} \mathbf{( 1 0 \%}$ Urea) & 8.03 & 8.95 & 8.49 \\
\hline Mean & 8.023 & 9.72 & 8.87 \\
\hline S.Ed & 0.609 & 0.433 & \\
\hline sssCD - 5\% & 1.298 & 0.923 & \\
\hline & $\mathbf{S . E d}$ & $\mathbf{C D}-\mathbf{5 \%}$ & \\
\hline Treatment & 0.371 & 0.755 & \\
\hline Season & 0.214 & 0.435 & \\
\hline Season x Treatment & 0.523 & 1.064 & \\
\hline
\end{tabular}


Table.3 Reducing sugar (\%)

\begin{tabular}{|l|c|c|c|}
\hline \multicolumn{1}{|c|}{ Treatment } & Rainy season & Winter season & Pooled \\
\hline $\mathbf{T}_{\mathbf{1}}(\mathbf{1 0 0} \mathbf{~ p p m ~ N A A )}$ & 2.92 & 3.68 & 3.30 \\
\hline $\mathbf{T}_{\mathbf{2}} \mathbf{( 4 0} \mathbf{~ p p m ~ N A D )}$ & 2.89 & 3.60 & 3.24 \\
\hline $\mathbf{T}_{\mathbf{3}}(\mathbf{6 0} \mathbf{~ p p m ~ N A D )}$ & 2.94 & 3.72 & 3.33 \\
\hline $\mathbf{T}_{\mathbf{4}}(\mathbf{2 \%}$ Urea) & 2.54 & 3.25 & 2.89 \\
\hline $\mathbf{T}_{\mathbf{5}} \mathbf{( 5 \%}$ Urea) & 2.64 & 3.48 & 3.06 \\
\hline $\mathbf{T}_{\mathbf{6}} \mathbf{( 1 0 \%}$ Urea) & 2.63 & 3.31 & 2.97 \\
\hline Mean & 2.76 & 3.51 & 3.13 \\
\hline S.Ed & 0.137 & 0.141 & \\
\hline CD $\mathbf{5 \%}$ & 0.293 & 0.302 & \\
\hline & S.Ed & $\mathbf{C D}-\mathbf{5 \%}$ & \\
\hline Treatment & 0.105 & 0.214 & \\
\hline Season & 0.061 & 0.125 & \\
\hline Season x Treatment & 0.148 & 0.301 & \\
\hline
\end{tabular}

Table.4 Non - reducing sugar (\%)

\begin{tabular}{|l|c|c|c|}
\hline \multicolumn{1}{|c|}{ Treatment } & Rainy season & Winter season & Pooled \\
\hline $\mathbf{T}_{\mathbf{1}}(\mathbf{1 0 0} \mathbf{~ p p m ~ N A A )}$ & 2.24 & 3.08 & 2.66 \\
\hline $\mathbf{T}_{\mathbf{2}} \mathbf{( 4 0} \mathbf{~ p p m ~ N A D )}$ & 2.14 & 3.07 & 2.61 \\
\hline $\mathbf{T}_{\mathbf{3}} \mathbf{( 6 0} \mathbf{~ p p m ~ N A D )}$ & 2.48 & 3.10 & 2.79 \\
\hline $\mathbf{T}_{\mathbf{4}} \mathbf{( 2 \%}$ Urea) & 2.08 & 2.78 & 2.43 \\
\hline $\mathbf{T}_{\mathbf{5}} \mathbf{( 5 \%}$ Urea) & 2.24 & 2.94 & 2.59 \\
\hline $\mathbf{T}_{\mathbf{6}} \mathbf{( 1 0 \%}$ Urea) & 2.13 & 2.86 & 2.49 \\
\hline Mean & 2.22 & 2.97 & 2.59 \\
\hline S.Ed & 0.028 & 0.021 & \\
\hline CD $\mathbf{5 \%}$ & 0.058 & 0.038 & \\
\hline & S.Ed & $\mathbf{C D}-\mathbf{5 \%}$ & \\
\hline Treatment & 0.026 & 0.054 & \\
\hline Season & 0.010 & 0.020 & \\
\hline Season Treatment & 0.038 & 0.077 & \\
\hline
\end{tabular}


Table.5 Total sugar content (\%)

\begin{tabular}{|l|c|c|c|}
\hline \multicolumn{1}{|c|}{ Treatment } & Rainy season & Winter season & Pooled \\
\hline $\mathbf{T}_{\mathbf{1}} \mathbf{( 1 0 0} \mathbf{~ p p m ~ N A A )}$ & 5.16 & 6.78 & 5.96 \\
\hline $\mathbf{T}_{\mathbf{2}} \mathbf{( 4 0} \mathbf{~ p p m ~ N A D )}$ & 5.03 & 6.67 & 5.85 \\
\hline $\mathbf{T}_{\mathbf{3}}(\mathbf{6 0} \mathbf{~ p p m ~ N A D )}$ & 5.42 & 6.82 & 6.12 \\
\hline $\mathbf{T}_{\mathbf{4}} \mathbf{( 2 \%}$ Urea) & 4.62 & 6.03 & 5.32 \\
\hline $\mathbf{T}_{\mathbf{5}} \mathbf{( 5 \%}$ Urea) & 4.88 & 6.42 & 5.65 \\
\hline $\mathbf{T}_{\mathbf{6}} \mathbf{( 1 0 \%}$ Urea) & 4.76 & 6.17 & 5.46 \\
\hline Mean & 4.98 & 6.48 & 5.73 \\
\hline S.Ed & 0.103 & 0.171 & \\
\hline CD - 5\% & 0.219 & 0.364 & \\
\hline & $\mathbf{S . E d}$ & $\mathbf{C D}-\mathbf{5 \%}$ & \\
\hline Treatment & 0.183 & 0.373 & \\
\hline Season & 0.068 & 0.138 & \\
\hline Season x Treatment & 0.163 & 0.332 & \\
\hline
\end{tabular}

Table.6 Sugar acid ratio

\begin{tabular}{|l|c|c|c|}
\hline \multicolumn{1}{|c|}{ Treatment } & Rainy season & Winter season & Pooled \\
\hline $\mathbf{T}_{\mathbf{1}} \mathbf{( 1 0 0} \mathbf{~ p p m ~ N A A )}$ & 18.42 & 42.25 & 30.33 \\
\hline $\mathbf{T}_{\mathbf{2}} \mathbf{( 4 0} \mathbf{~ p p m ~ N A D )}$ & 17.34 & 39.23 & 28.28 \\
\hline $\mathbf{T}_{\mathbf{3}}(\mathbf{6 0} \mathbf{~ p p m ~ N A D )}$ & 20.84 & 45.46 & 33.15 \\
\hline $\mathbf{T}_{\mathbf{4}} \mathbf{( 2 \%}$ Urea) & 12.83 & 24.12 & 18.47 \\
\hline $\mathbf{T}_{\mathbf{5}} \mathbf{( 5 \%}$ Urea) & 15.25 & 27.91 & 21.58 \\
\hline $\mathbf{T}_{\mathbf{6}} \mathbf{( 1 0 \%}$ Urea) & 14.24 & 25.71 & 19.97 \\
\hline Mean & 16.48 & 34.11 & 25.29 \\
\hline S.Ed & 0.020 & 0.071 & \\
\hline CD $\mathbf{5 \%}$ & 0.045 & 0.152 & \\
\hline & $\mathbf{S . E d}$ & $\mathbf{C D}-\mathbf{5 \%}$ & \\
\hline Treatment & 0.033 & 0.067 & \\
\hline Season & 0.012 & 0.025 & \\
\hline Season $\mathbf{~ T r e a t m e n t ~}$ & 0.193 & 0.095 & \\
\hline
\end{tabular}


Table.7 Pectin (\%)

\begin{tabular}{|l|c|c|c|}
\hline \multicolumn{1}{|c|}{ Treatment } & Rainy season & Winter season & Pooled \\
\hline $\mathbf{T}_{\mathbf{1}}(\mathbf{1 0 0} \mathbf{~ p p m ~ N A A )}$ & 2.61 & 3.36 & 2.98 \\
\hline $\mathbf{T}_{\mathbf{2}} \mathbf{( 4 0} \mathbf{~ p p m ~ N A D )}$ & 2.43 & 3.29 & 2.86 \\
\hline $\mathbf{T}_{\mathbf{3}}(\mathbf{6 0} \mathbf{~ p p m ~ N A D )}$ & 2.86 & 3.42 & 3.14 \\
\hline $\mathbf{T}_{\mathbf{4}}(\mathbf{2 \%}$ Urea) & 1.72 & 3.11 & 2.41 \\
\hline $\mathbf{T}_{\mathbf{5}} \mathbf{( 5 \%}$ Urea) & 2.32 & 3.21 & 2.76 \\
\hline $\mathbf{T}_{\mathbf{6}}(\mathbf{1 0 \%}$ Urea) & 2.10 & 3.17 & 2.63 \\
\hline Mean & 2.34 & 3.26 & 2.79 \\
\hline S.Ed & 0.029 & 0.026 & \\
\hline CD $\mathbf{5 \%}$ & 0.062 & 0.056 & \\
\hline & S.Ed & $\mathbf{C D}-\mathbf{5 \%}$ & \\
\hline Treatment & 0.012 & 0.024 & \\
\hline Season & 0.031 & 0.064 & \\
\hline Season x Treatment & 0.044 & 0.090 & \\
\hline
\end{tabular}

Table.8 Ascorbic acid (mg/100g)

\begin{tabular}{|l|c|c|c|}
\hline \multicolumn{1}{|c|}{ Treatment } & Rainy season & Winter season & Pooled \\
\hline $\mathbf{T}_{\mathbf{1}} \mathbf{( 1 0 0} \mathbf{~ p p m ~ N A A )}$ & 135.69 & 254.90 & 195.30 \\
\hline $\mathbf{T}_{\mathbf{2}} \mathbf{( 4 0} \mathbf{~ p p m ~ N A D )}$ & 126.51 & 232.73 & 179.62 \\
\hline $\mathbf{T}_{\mathbf{3}} \mathbf{( 6 0} \mathbf{~ p p m ~ N A D )}$ & 142.20 & 264.18 & 203.19 \\
\hline $\mathbf{T}_{\mathbf{4}} \mathbf{( 2 \%}$ Urea) & 92.11 & 128.42 & 110.26 \\
\hline $\mathbf{T}_{\mathbf{5}} \mathbf{( 5 \%}$ Urea) & 104.19 & 154.17 & 129.18 \\
\hline $\mathbf{T}_{\mathbf{6}} \mathbf{( 1 0 \%}$ Urea) & 101.50 & 132.26 & 116.88 \\
\hline Mean & 117.04 & 194.45 & 155.74 \\
\hline S.Ed & 1.009 & 1.675 & \\
\hline CD - 5\% & 2.150 & 3.568 & \\
\hline & S.Ed & CD-5\% & \\
\hline Treatment & 0.835 & 1.700 & \\
\hline Season & 0.309 & 0.628 & \\
\hline Season x Treatment & 1.182 & 2.404 & \\
\hline
\end{tabular}


Table.9 Juice content (\%)

\begin{tabular}{|l|c|c|c|}
\hline \multicolumn{1}{|c|}{ Treatment } & Rainy season & Winter season & Pooled \\
\hline $\mathbf{T}_{\mathbf{1}}(\mathbf{1 0 0} \mathbf{~ p p m ~ N A A )}$ & 45.64 & 46.87 & 46.25 \\
\hline $\mathbf{T}_{\mathbf{2}} \mathbf{( 4 0} \mathbf{~ p p m ~ N A D )}$ & 43.16 & 42.23 & 42.69 \\
\hline $\mathbf{T}_{\mathbf{3}} \mathbf{( 6 0} \mathbf{~ p p m ~ N A D )}$ & 46.28 & 48.45 & 47.37 \\
\hline $\mathbf{T}_{\mathbf{4}} \mathbf{( 2 \%}$ Urea) & 34.76 & 36.56 & 35.66 \\
\hline $\mathbf{T}_{\mathbf{5}} \mathbf{( 5 \%}$ Urea) & 42.62 & 41.25 & 41.93 \\
\hline $\mathbf{T}_{\mathbf{6}} \mathbf{( 1 0 \%}$ Urea) & 38.22 & 40.12 & 39.17 \\
\hline Mean & 41.78 & 42.58 & 42.18 \\
\hline S.Ed & 0.860 & 0.570 & \\
\hline CD - 5\% & 1.832 & 1.214 & \\
\hline & S.Ed & $\mathbf{C D}-\mathbf{5 \%}$ & \\
\hline Treatment & 0.487 & 0.990 & \\
\hline Season & 0.249 & 0.506 & \\
\hline Season x Treatment & 0.785 & 1.597 & \\
\hline
\end{tabular}

\section{Ascorbic acid}

The data presented in Table 8 revealed that, the significant differences in ascorbic acid content of fruits was due to various treatments. The highest ascorbic acid content of $142.20 \mathrm{mg} / 100$ $\mathrm{g}$ and $264.18 \mathrm{mg} / 100 \mathrm{~g}$ was recorded in $\mathrm{T}_{3}(60$ ppm NAD) followed by $135.69 \mathrm{mg} / 100 \mathrm{~g}$ and $254.90 \mathrm{mg} / 100 \mathrm{~g}$ in $\mathrm{T}_{1}$ (100 ppm NAA) during the rainy and the winter season respectively. The interaction effect of treatments and seasons were found to be significant. The highest ascorbic acid content of $203.19 \mathrm{mg} / 100 \mathrm{~g}$ was recorded in $T_{3}$ (60 ppm NAD) followed by $195.30 \mathrm{mg} / 100 \mathrm{~g}$ in $\mathrm{T}_{1}$ (100 ppm NAA). The lowest ascorbic acid content $(110.26 \mathrm{mg} / 100 \mathrm{~g})$ was recorded under $\mathrm{T}_{4}$ (2\% Urea). The highest ascorbic acid content in winter season guava fruits than in those harvested from spring flushed crop might be ascribed due to the effect of low temperature. The low temperature governs the enzymatic system involved in biogenesis and catabolism of ascorbic acid. The increase in ascorbic acid also might be due to catalytic activity of plant bioregulators on its biosynthesis from its precursor glucose-6- phosphate or inhibition of its conversion into dehydro ascorbic acid by enzyme ascorbic acid oxidase or both.

\section{Juice content}

The data shown in Table 9 revealed that $\mathrm{T}_{3}(60$ ppm NAD) recorded the highest juice content of $46.28 \%$ and $48.45 \%$ followed by $45.64 \%$ and $46.87 \%$ in $\mathrm{T}_{1}$ (100 ppm NAA) during both the rainy and the winter season. The interaction effect of seasons and treatments were found to be significant. The highest juice content of $46.25 \%$ was recorded under $\mathrm{T}_{1}(100 \mathrm{ppm}$ NAA) followed by $45.86 \%$ under $\mathrm{T}_{3}(60 \mathrm{ppm}$ NAD). However, the treatment $\mathrm{T}_{1}(100 \mathrm{ppm}$ NAA) was statistically at par with $\mathrm{T}_{3}(60$ ppm NAD) and treatment $\mathrm{T}_{2}$ (40 ppm NAD) were statistically at par with $\mathrm{T}_{5}(5 \%$ Urea). The increase in juice content in the winter season might be due to increase in pulp content, TSS content, less amount of seeds, increase in ascorbic acid, decrease in titrable acidity.

It has been found from the present experiment that, 60 ppm NAD treatment significantly 
helped in deblossoming of flowers in the rainy season and increased the yield along with TSS content, reducing sugar, non-reducing sugar, total sugar, ascorbic acid and decrease in titrable acidity in the winter season.

From the results, it can be concluded that, 60 ppm NAD proved to be the best chemical treatment for enhancing the quality and production of highly remunerative crop.

\section{References}

Anonymous (2015). National Horticulture database. National Horticulture Board. Govt. of India, Gurgaon, India. http./www.nhb.gov.in

Boora, R.S., Dhaliwal, H.S. and Arora, N.K. (2016). Crop regulation in Guava. Ind. J. Agri. 37(1): 1-9.

Dubey, A.K., Singh, D.B. and Neeru, D. (2002). Crop regulation in guava (Psidium guajava L.) cv. Allahabad Safeda. Prog. Hort. 34: 200-203.

Dubey, A.K., Singh, D.B.; Barche, S.; Singh, A. and Dalal, M. (2002). Deblossoming in summer season flowering in guava. Ind. Hort. 4: 35-36.

Dutta, P. and Banik, A.K. (2006). Influence of plant bio-regulators on yield, physicochemical qualities and leaf mineral composition of Sardar guava grown in redand laterite tract of West Bengal. Hort. J. 19 (3): 356-357.

Kumar, R. and Hoda, M.N. (1977). Crop regulation studies in Allahabad Safeda guava. Ind. J. Hort. 34(1): 13-15.

Kumar, R. (2012). Quantitative and Qualitative Enhancement of Guava (Psidium guajava L.) cv. Chittidar through Foliar Feeding. M.Sc. thesis submitted to Rajmata Vijayarajel Scindia Krishi Vishwa Vidyalaya, Gwalior (M.P.).
Maji, S.; Das, B.C. and Sarkar, S.K. (2015). Scientia Horticulturae. (188): 66.

Mitra, S.K.; Sen, S. K.; Maiti, S. C. and Bose, T. K. (1982). Effect of growth substances on deblossoming regulation of cropping and fruit quality in guava. Hort $J$. 1: 81 .

Ojah, D. (2013). Crop Regulation in Guava (Psidium guajava L.) M.Sc. Thesis submitted to Assam Agricultural University, Jorhat.

Panse, V.G. and Sukhatma, P.V. (1985). Statistical Methods for Agricultural Workers, $4^{\text {th }}$ edn, ICAR, New Delhi.

Rajput, C.B.S.; Singh, S.N. and Singh, N.P. (1977). Effect of certain plant growth substances in guava (Psidium guajava L.). Haryana J. Hort. Sci. 6(3-4):117-119.

Sanjay, S. and Kumar, N. (2004). Crop regulation and quality control in guava (Psidium guajava L.). Prog. Hort. 36(1): 152-154.

Shankar, R. (2003). Crop Regulation in Guava (Psidium guajava L.) cv. Arka Mridula. Thesis submitted to Birsa Agricultural University, Ranchi.

Sharma, A.; Wali, V. K.; Sharma, R.M. and Sharma, B. (2016). Effectiveness of various crop regulation treatments. An Int. Quart. J. Life Sci. 11(1): 335-338.

Singh, G. (2008). High Density and Meadow Orcharding of Guava. Central Institute for Subtropical Horticulture. 1-8.

Singh, R.; Singh, S.N.; Gupta, M.R.; Dhaliwal, G.S. and Kalra, S.K. (1992). Studies on winter cropping in guava cv. Allahabad Safeda. Ind. J. Hort. 49(2): 127-133.

Singh, U.P. (1986). Crop regulation studies in guava. Ph.D. thesis submitted to RAU, Pusa Bihar Agriculure College, Sabour, Bihar.

Tiwari, J. P and Lal, S. (2007). Effect of NAA, flower bud thinning and pruning on crop regulation in guava cv. Sardar. Acta Hort. 735: 311- 314 .

\section{How to cite this article:}

Divyashree Saikia and Utpal Kotoky. 2019. Study the Efficacy of Chemicals on the Quality Parameters of Guava (Psidium guajava L) cv. Lucknow - 49. Int.J.Curr.Microbiol.App.Sci. 8(01): 1436-1445. doi: https://doi.org/10.20546/ijcmas.2019.801.153 